\title{
AN INORGANIC FUNCTIONAL GROUP APPROACH TO THE SYSTEMATIC SYNTHESIS AND REACTIVITY STUDIES OF BINUCLEAR Mo/S AND Mo/S/O COMPLEXES
}

\author{
D. COUCOUVANIS, ${ }^{*}$ A. TOUPADAKIS, SANG-MAN KOO and \\ A. HADJIKYRIACOU
}

Department of Chemistry, The University of Michigan, Ann Arbor, MI 48109, U.S.A.

\begin{abstract}
A number of general reactions, based on molybdenum-coordinated sulphido or polysulphido ligands, can account for the synthesis of many members of the $\left[\mathrm{Mo}_{2}^{\mathrm{V}}\right.$ $\left.(\mathrm{S})_{n}\left(\mathrm{~S}_{2}\right)_{6-n}\right]^{2-},\left[\mathrm{Mo}_{2}^{\mathrm{V}}(\mathrm{O})(\mathrm{S})_{n}\left(\mathrm{~S}_{2}\right)_{5-n}\right]^{2-}$ and $\left[\mathrm{Mo}_{2}(\mathrm{O})_{2}(\mathrm{~S})_{n}\left(\mathrm{~S}_{2}\right)_{4-n}\right]^{2-}$ homologous series. These reactions include: (a) sulphur addition and sulphur abstraction reactions; (b) oxidative removal of the $S_{x}^{2-}$ ligands and their replacement by substitutionally labile ligands; (c) oxidation of coodinated $\mathrm{RS}^{-}$ligands by $\mathrm{S}_{x}^{0}$ fragments, and in situ generation of $\mathrm{S}_{x}^{2-}$ ligands ; (d) oxidative dimerization reactions of molybdenum(IV) complexes; and (e) reductive elimination of $\mathrm{S}_{x}^{0}$ fragments. The synthesis of the new $\left[(\mathrm{Cp}) \mathrm{Mo}^{\mathrm{v}}(\mathrm{O})(\mu-\mathrm{S})_{2} \mathrm{Mov}^{\mathrm{v}}(\mathrm{O}) \mathrm{S}_{4}\right]^{-}$and $\left[(\mathrm{Cp}) \mathrm{Mo}^{\mathrm{v}}(\mathrm{O})(\mu-\mathrm{S})_{2} \mathrm{Mo}^{\mathrm{v}}(\mathrm{O}) \mathrm{S}_{2}\right]^{-}$anions has alowed the use of ${ }^{1} \mathrm{H}$ NMR spectroscopy to monitor the solution behaviour and reactivity of the $\mathrm{Mo}^{\mathrm{v}}(\mathrm{O}) \mathrm{S}_{2}$ group. The existence of the $\mathrm{Mo}^{\mathrm{v}}(\mathrm{O}) \mathrm{S}_{2}+\mathrm{S}_{2} \rightleftarrows \mathrm{Mo}^{\mathrm{v}}(\mathrm{O}) \mathrm{S}_{4}$ equilibrium has been unequivocally established. The [(Cp)Mov (O) $\left(\mu-\mathrm{S}_{2} \mathrm{Mo}^{\mathrm{v}}(\mathrm{O}) \mathrm{S}_{2}\right]^{-}$complex gives a vinyl disulphide derivative by insertion of dicarbomethoxyacetylene, DMA, into the $\mathrm{Mo}-\eta^{2}-\mathrm{S}_{2}$ group. Upon prolonged heating to $70^{\circ} \mathrm{C}$ the vinyl disulphide ligand is converted quantitatively to a dithiolene ligand. The same conversion takes place swiftly at ambient temperatures when catalytic amounts of $S_{8}$ are present in the reaction medium. Reaction pathways for both the thermal and catalytic conversions have been suggested by ${ }^{1} \mathrm{H}$ NMR studies. Preliminary studies of the utility of the $\left(\mathrm{Et}_{4} \mathrm{~N}\right)\left[\mathrm{Mo}_{2} \mathrm{O}_{2} \mathrm{~S}_{8} \mathrm{Cl}\right],\left[\mathrm{Ni}(\mathrm{DMF})_{6}\right]\left[\mathrm{Mo}_{2} \mathrm{O}_{2} \mathrm{~S}_{8} \mathrm{Cl}\right]_{2},\left(\mathrm{Et}_{4} \mathrm{~N}\right)_{2}\left[\mathrm{Mo}_{4} \mathrm{O}_{4} \mathrm{~S}_{18}\right]$ and $\left(\mathrm{Ph}_{4} \mathrm{P}\right)_{2}\left[\mathrm{Mo}_{2} \mathrm{~S}_{6}\right]$ complexes as catalysts for the hydrodesulphurization of thiophene are reported. $\mathrm{The} \mathrm{Ni} / \mathrm{Mo}$ catalyst obtained from $\left[\mathrm{Ni}(\mathrm{DMF})_{6}\right]\left[\mathrm{Mo}_{2} \mathrm{O}_{2} \mathrm{~S}_{8} \mathrm{Cl}\right]_{2}$ is at least 10 times more effective than a commercial Co/Mo catalyst.
\end{abstract}

The binary, $\mathrm{Mo} / \mathrm{S}$, or tertiary, $\mathrm{Mo} / \mathrm{S} / \mathrm{O}$, thiomolybdate complexes ${ }^{1-4}$ are characterized by a remarkable complexity in structure and by interesting reactivity characteristics. The vast majority of these complexes are anionic species and can be described in terms of various combinations of the $\mathrm{O}^{2-}, \mathrm{S}^{2-}, \mathrm{S}_{2}^{2-}$ and $\mathrm{S}_{4}^{2-}$ ligands coordinated to molybdenum(IV), -(V) or -(VI) ions.

At times, the deceivingly simple procedures that

*Author to whom correspondence should be addressed.

$\dagger$ For the neutral free atoms, a compilation of Roothaan-Hartree-Fock atomic wavefunctions ${ }^{5}$ show the sulphur $3 p$ orbitals with an energy of -0.43694 a.u. and the molybdenum $4 d\left(s^{1} d^{5}\right)$ with an energy of 0.34811 a.u. The localization of partial positive charge on the molybdenum and partial negative charge on the sulphur is expected to bring these energies even closer together. are used in the synthesis of some of these compounds result in products with unexpected formal oxidation states for the molybdenum atoms and the appearance of sulphur ligands in various degrees of catenation. The latter phenomena have their origin in facile intramolecular electron transfer processes that derive from a close matching of the $S 3 p$ and Mo $4 d$ orbital energies. $f$ An example of intramolecular electron transfer can be found in the synthesis of the $\left[\left(\mathrm{S}_{4}\right)_{2} \mathrm{Mo}^{\mathrm{IV}}=\mathrm{S}\right]^{2-}$ and $\left[\left(\mathrm{S}_{4}\right)_{2} \mathrm{Mo}^{\mathrm{IV}}=\right.$ $\mathrm{O}^{2-}$ anions $^{6}$ (Figs 1 and 2). These anions are obtained by the reaction of $\mathrm{S}_{8}$ with $\left[\mathrm{Mo}^{\mathrm{VI}} \mathrm{S}_{4}\right]^{2-}$ or $\left[\mathrm{Mo}^{\mathrm{vI}} \mathrm{S}_{x} \mathrm{O}_{4-x}\right]^{2-}$ under oxidizing conditions! Intramolecular electron transfer also accounts for an apparent diversity in structural isomerism for certain molybdothioanions, where $S-S$ bonds break or form as molybdenum atoms are oxidized or reduced. ${ }^{2}$

Our exploration of the reactivities of the coor- 


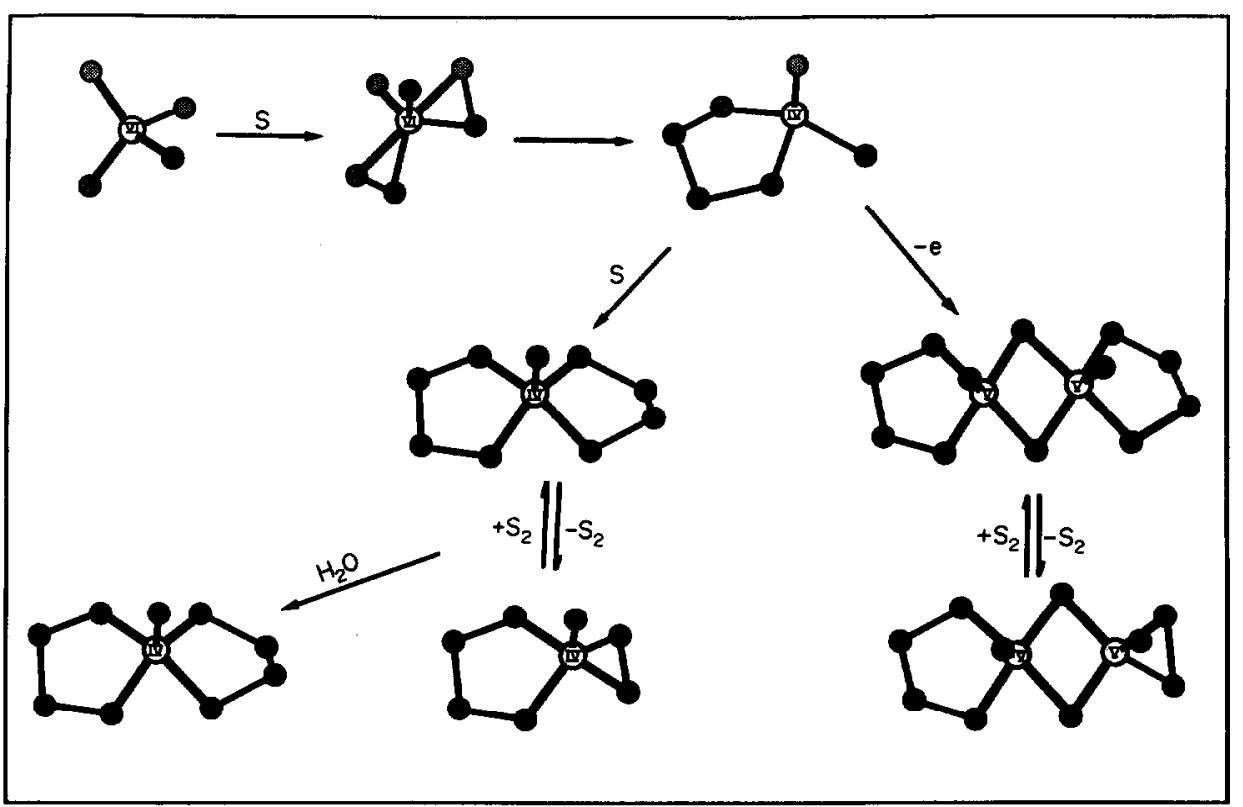

Fig. 1. Possible reaction pathways for the syntheses of the $\left[\left(\mathrm{S}_{4}\right)_{2} \mathrm{Mo}^{\mathrm{IV}}=\mathrm{S}\right]^{2-}$ and $\left[\left(\mathrm{S}_{4}\right) \mathrm{Mo}^{\mathrm{v}}=\mathrm{S}(\mu-\mathrm{S})\right]_{2}^{2-}$ complexes by the reaction of $\mathrm{S}_{8}$ with the $\left[\mathrm{MoS}_{4}\right]^{2-}$ anion.

dinated $\mathrm{S}^{2-}, \mathrm{S}_{2}^{2-}$ and $\mathrm{S}_{4}^{2-}$ ligands has revealed a number of reliable general reactions that can be used for the systematic synthesis of certain thiomolybdates. Furthermore, these studies have made it apparent that neighbouring ligands, and the molybdenum oxidation state, have profound influence on reactivity.

In this paper we report on general reactivity patterns of the molybdenum-coordinated $\mathrm{S}^{2-}, \mathrm{S}_{2}^{2-}$ and $\mathrm{S}_{4}^{2-}$ ligands. These first attempts in the development of "functional group" chemistry in the $\mathrm{Mo} / \mathrm{S}$ and $\mathrm{Mo} / \mathrm{S} / \mathrm{O}$ complexes have led to rational syntheses of homologous series of complexes such as $\left[\mathrm{Mo}_{2}^{\mathrm{v}}\right.$ $\left.(\mathrm{S})_{n}\left(\mathrm{~S}_{2}\right)_{6-n}\right]^{2-2}$ and $\left[\mathrm{Mo}_{2}^{\mathrm{V}}(\mathrm{O})(\mathrm{S})_{n}\left(\mathrm{~S}_{2}\right)_{5-n}\right]^{2-7}$ and a better understanding of the reactions of these complexes with activated alkynes and $\mathrm{CS}_{2}$.

The synthesis of homologous series of Mo/S and Mo/S/O binary and tertiary complex anions makes it possible to systematically evaluate their activity, and the activity of their $\mathrm{Ni}^{2+}$ or $\mathrm{Co}^{2+}$ "salts" in the hydrodesulphurization (HDS) reaction of thiophene. In this paper we also report preliminary results on the catalytic properties of certain $\gamma-\mathrm{Al}_{2} \mathrm{O}_{3}$ supported, thiomolybdate complexes.

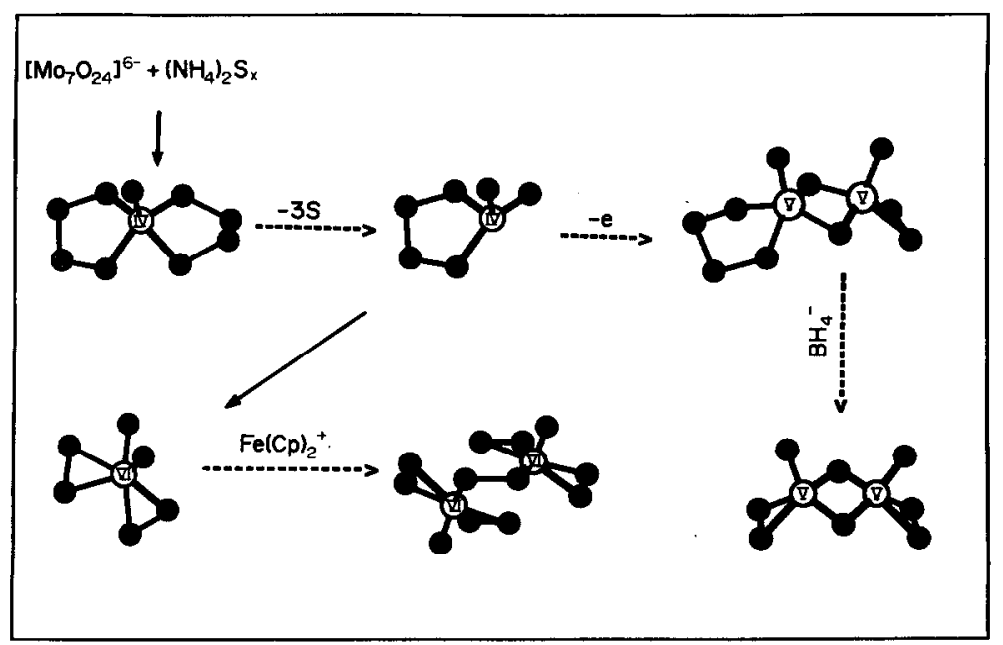

Fig. 2. Possible reaction pathways in the syntheses of the $\left[\left(\mathrm{S}_{4}\right) \mathrm{Mo}^{\mathrm{v}}=\mathrm{O}(\mu-\mathrm{S})\right]_{2}^{2-} ;\left[\left(\mathrm{S}_{2}\right) \mathrm{Mo}^{\mathrm{v}}=\mathrm{O}(\mu-\mathrm{S})\right]_{2}^{2-}$ and $\left[\left(\mathrm{S}_{2}\right)_{2} \mathrm{Mo}^{\mathrm{VL}}=\mathrm{O}(\mathrm{S})\right]_{2}^{2-}$ complexes. 


\section{DISCUSSION}

\section{Synthesis of molybdothioanions}

A number of general reactions, based on molybdenum-coordinated sulphido or polysulphido ligands, can account for the synthesis of many members of the $\left[\mathrm{Mo}_{2}^{\mathrm{V}}(\mathrm{S})_{n}\left(\mathrm{~S}_{2}\right)_{6-n}\right]^{2-2},\left[\mathrm{Mo}_{2}^{\mathrm{V}}(\mathrm{O})(\mathrm{S})_{n}\right.$ $\left.\left(\mathrm{S}_{2}\right)_{5-n}\right]^{2-7}$ and $\left[\mathrm{Mo}_{2}^{\mathrm{V}}(\mathrm{O})_{2}(\mathrm{~S})_{n}\left(\mathrm{~S}_{2}\right)_{4-n}\right]^{2-8,9}$ homologous series. Furthermore, these reactions make it possible to design procedures for the synthesis of new thiomolybdate complexes. In the discussion that follows, a detailed account is offered for the synthesis and reactivities of the molybdenumcoordinated sulphido and persulphido functional groups.

\section{The molybdenum-coordinated $\mathbf{S}^{2-}$ ligands}

The reactions of oxomolybdates $\left[\left(\mathrm{Mo}^{\mathrm{vI}} \mathrm{O}_{4}\right)^{2-}\right.$ or $\left.\left(\mathrm{Mo}_{7}^{\mathrm{VI}} \mathrm{O}_{24}\right)^{6-}\right]$ with $\mathrm{H}_{2} \mathrm{~S}$ or $\left(\mathrm{NH}_{4}\right)_{2} \mathrm{~S}_{x}$ under basic conditions give thiomolybdate products that, depending on reaction times or conditions, contain $\mathrm{Mo}-\mathrm{S}_{x}$ and $\mathrm{Mo}=\mathrm{O}$ units in various combinations. The simplest among the $S_{x}^{2-}$ ligands is the $S^{2-}$ ligand that exists mainly as: (a) a terminal ligand in thiomolybdenyl units ${ }^{1-3}\left(\mathrm{Mo}^{n+}=\mathrm{S}, n=\mathrm{IV}, \mathrm{V}, \mathrm{VI}\right)$, (b) a $\mu_{2}$-bridging unit in cores such as $\left(\mathrm{Mo}_{2} \mathrm{~S}_{2}\right)^{6+1-4}$ and (c) a $\mu_{3}$-bridging unit in $\left[\mathrm{Mo}_{3} \mathrm{~S}_{13}\right]^{2-10}$ and in the $\mathrm{Mo}_{4} \mathrm{~S}_{4}$ cores of the $\left[\left(\mathrm{L}_{3} \mathrm{Mo}\right)_{2} \mathrm{~S}_{4}\right]$ complexes ${ }^{11,12}$ and in $\left[\mathrm{Mo}_{7} \mathrm{~S}_{8}\left(\mathrm{H}_{2} \mathrm{O}\right)_{18}\right]^{8+} .{ }^{13}$ The nucleophilicity that dominates the chemistry of the $\mathrm{S}^{2-}$ ligands depends on the coordination mode [(a), (b) or (c) above] and appears to be stronger for the terminal $\mathrm{Mo}=\mathrm{S}$ sulphido ligands. In this paper we will direct our attention to the chemistry of the $\mathrm{S}^{2-}$ terminal ligands.

The addition of sulphur to terminal sulphido ligands is very likely the end result of electrophilic attack on the $\mathrm{Mo}^{n+}=\mathrm{S}$ sulphur by the ${ }^{+} \mathrm{S}(\mathbf{S})_{\mathrm{x}} \mathrm{S}^{-}$ products of heterolytically cleaved $\mathbf{S}_{\mathbf{8}}$ molecules. This general reaction occurs readily with various $\mathrm{Mo}^{n+}=\mathrm{S}$ groups $(n=\mathrm{IV}, \mathrm{V}, \mathrm{VI})$ and is encouraged in the synthesis of the $\left[\left(\mathrm{S}_{4}\right)_{2} \mathrm{Mo}^{I V}=\mathrm{E}\right]^{2-}$ anions $^{6}$ $(\mathrm{E}=\mathrm{S}, \mathrm{O}$; Fig. 1) and various members of the $\left[\mathrm{Mo}_{2}^{\mathrm{V}}(\mathrm{S})_{n}\left(\mathrm{~S}_{2}\right)_{6-n}\right]^{2-2}$ (Fig. 3) and $\left[\mathrm{Mo}_{2}^{\mathrm{V}}(\mathrm{O})(\mathrm{S})_{n}\right.$ $\left.\left(\mathrm{S}_{2}\right)_{5-n}\right]^{2-7}$ series. Addition of sulphur atoms to the $\mathrm{Mo}=S$ units gives stable $M o-\eta^{2}-S_{2}$ units that on occasion may undergo subsequent intramolecular electron transfer on their way to more stable, electron redistribution isomers (Figs 1 and 2). Electrophilic attack on the $\mathrm{Mo}^{n+}=\mathrm{S}$ sulphur very likely also occurs in the reactions of various thiomolybdates with $\mathrm{CS}_{2}{ }^{14}$ and activated alkynes, $\mathrm{RC} \equiv \mathrm{CR},{ }^{1,15}$ (vide infra).

With transition metal ions, the thiomolybdenyl groups can serve as either electron pair donors, or as a source of sulphide ions for the eventual formation of highly insoluble, thermodynamically stable, transition metal sulphides. The former course of reactivity is aptly represented in the multitude of heterometallic complexes where the $\mathrm{MoS}_{4}^{2-}$ anion serves as a ligand for transition metal ions. ${ }^{16}$ The irreversible removal of sulphide ions from $\mathrm{Mo}=\mathrm{S}$ units by the formation of insoluble transition metal sulphides allows for the introduction of non-sulphur terminal ligands in the thiomolybdate ions by metathetical reactions. An example of this reaction is available in the synthesis of the $\left[\mathrm{Mo}_{2} \mathrm{O}_{2} \mathrm{~S}_{8} \mathrm{X}\right]^{-}$anions ${ }^{17}$ from the reaction

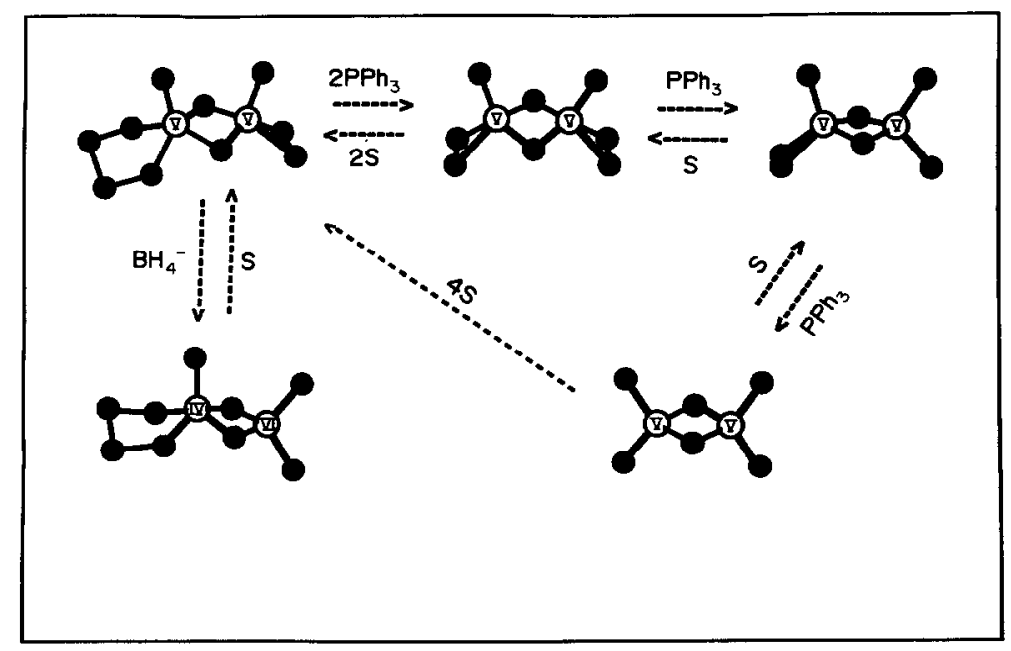

Fig. 3. The syntheses of members in the $\left[\mathrm{Mo}_{2}^{\mathrm{V}}(\mathbf{S})_{n}\left(\mathbf{S}_{2}\right)_{6-n}\right]^{2-}$ series by sulphur addition and sulphurabstraction reactions. 


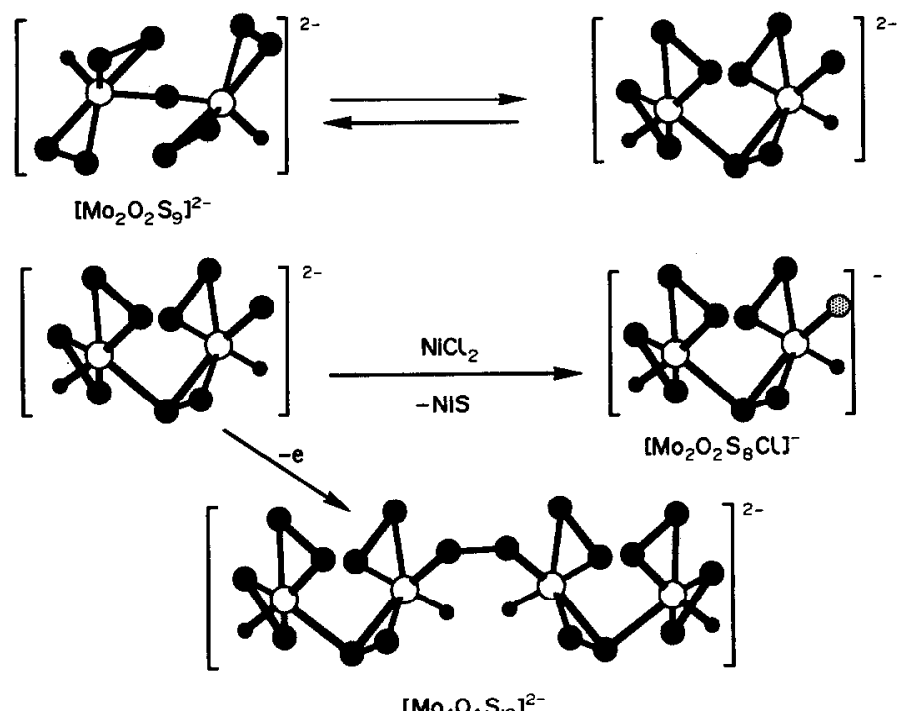

Fig. 4. Reactions and derivatives of the $\left[\left[\left(\mathrm{S}_{2}\right)_{2} \mathrm{Mo}^{\mathrm{VL}}=\mathrm{O}\right]_{2}(\mathrm{~S})\right]^{2-}$ anion.

of $\mathrm{NiX}_{2}(\mathrm{X}=\mathrm{Cl}, \mathrm{I})$ with an isomeric form of the $\left[\mathrm{Mo}_{2}^{\mathrm{VI}} \mathrm{O}_{2} \mathrm{~S}_{9}\right]^{2-}$ anion ${ }^{18}$ (Fig. 4). The latter is obtained readily by oxidation of the $\left[\left(\mathrm{S}_{4}\right)_{2}\right.$ $\left.\mathrm{Mo}^{\mathrm{IV}}=\mathrm{O}\right]^{2-}$ anion (Fig. 2).

The oxidation of the thiomolybdenyl group by various oxidizing agents depends on the formal oxidation state of the molybdenum atom and the nature of the neighbouring ligands in the coordination sphere of the molybdenum atom. The dimerization of $\mathrm{Mo}^{\mathrm{v}}, 4 d^{1}$ complexes to diamagnetic dimeric complexes with a formal Mo-Mo single bond is well documented. Not surprisingly, the one-electron oxidations of $(\mathrm{L})_{n} \mathrm{Mo}^{\mathrm{IV}}=\mathrm{S}$ complexes invariably lead to dimerization with formation of the very stable di- $\mu$-sulphido $\left[(\mathrm{L})_{n} \mathrm{Mo}^{\mathrm{v}} \mathrm{S}\right]_{2}$ products.

Examples of this oxidative dimerization include the formation of $\left[\left(\mathrm{S}_{4}\right) \mathrm{SMo}^{\mathrm{v}}=\mathrm{E}\right]_{2}^{2-}$ from the airoxidation of $\left[\left(\mathrm{S}_{4}\right)_{2} \mathrm{Moo}^{\mathrm{IV}}=\mathrm{E}\right]^{2-7}$ (Figs 1 and 2 ), and the formation of the $\left[(\mathrm{L})_{2} \mathrm{Mo}^{\mathrm{V}}=\mathrm{S}\right]_{2}^{2-}$ dimer $^{1}$ apparently from the oxidation of an unstable $\left[(\mathrm{L})_{2}\right.$ $\left.\mathrm{Mo}^{\mathrm{IV}}=\mathrm{S}\right]^{2-}$ intermediate $(\mathrm{L}=1,2$-dicarboethoxyethylene-1,2-diethiolate). An unusual oxidation is evident in the reaction of the $\left[\left(\mathrm{S}_{4}\right)_{2} \mathrm{Mo}^{\mathrm{IV}}=\mathrm{O}\right]^{2-}$ complex with $\left[\left(\mathrm{C}_{5} \mathrm{H}_{5}\right)_{2} \mathrm{Fe}\right]^{+}$, and formation of the $\left[\left(\mathrm{S}_{2}\right)_{2}(\mathrm{O}) \mathrm{Mo}^{\mathrm{vI}}-\mathrm{S}-\mathrm{S}-\mathrm{Mo}^{\mathrm{VI}}(\mathrm{O})\left(\mathrm{S}_{2}\right)_{2}\right]^{2-} \operatorname{dimer}^{17}$ (Fig. 2). This oxidation may involve the $\left[\left(\mathrm{S}_{2}\right)_{2}(\mathrm{O})\right.$ $\left.\mathrm{Mo}^{\mathrm{VL}}=\mathrm{S}\right]^{2-}$ intermediate complex that forms as a result of intramolecular electron transfer. The $\left[\left(\mathrm{S}_{2}\right)_{2}(\mathrm{O}) \mathrm{Mo}^{\mathrm{VI}}\left(\mu-\mathrm{S}_{2}\right) \mathrm{Mo}^{\mathrm{VI}}(\mathrm{O})\left(\mathrm{S}_{2}\right)_{2}\right]^{2-}$ dimer (Fig. 2) readily dissociates sulphur to give the apparently more stable $\left[\left(\mathrm{S}_{2}\right)_{2}(\mathrm{O}) \mathrm{Mo}^{\mathrm{vI}}-\mathrm{S}-\mathrm{Mo}^{\mathrm{VI}}(\mathrm{O})\left(\mathrm{S}_{2}\right)_{2}\right]^{2-}$ complex.

\section{The molybdenum-coordinated $\mathrm{S}_{2}^{2-}$ ligands}

As discussed previously, the $\mathrm{Mo}^{n+}-\eta^{2}-\mathrm{S}_{2}$ units are obtained by sulphur addition to the $\mathrm{Mo}^{n+}=\mathrm{S}$ units $(n=\mathrm{IV}, \mathrm{V}, \mathrm{VI})$. The same units also can be obtained by the oxidation of molybdenum-coordinated $\mathrm{PhS}^{-}$ligands with the dibenzyltrisulphide reagent. This general reaction generates $S_{x}^{2-}$ ligands in situ, from the reduction of $\mathrm{S}_{x}^{0}$ fragments by $\mathrm{PhS}^{-}$ ligands, and has been used previously ${ }^{19}$ in the synthesis of $\left[\mathrm{M}\left(\mathrm{S}_{x}\right)_{2}\right]^{2-}$ complexes from the $\left[\mathrm{M}(\mathrm{SPh})_{4}\right]^{2 \cdots}$ anions. The oxidative removal of the coordinated $\mathrm{PhS}^{-}$ligands from the [OMov $\left.(\mathrm{SPh})_{2} \mathrm{MoS}_{4}\right]^{2-}$ derivative ${ }^{7}$ of the $\left[\mathrm{OMo}^{\mathrm{v}}(\mathrm{SPh})_{4}\right]^{-}$ complex, ${ }^{20}$ with the concomitant introduction of the $\eta^{2}-\mathrm{S}_{2}$ ligand, is shown in Fig. 5. This reaction and subsequent sulphur-addition or sulphurabstraction reactions have made possible the rational synthesis of the new $\left[\mathrm{Mo}_{2}^{\mathrm{v}}(\mathrm{O})(\mathrm{S})_{n}\left(\mathrm{~S}_{2}\right)_{5-n}\right]^{2-}$ anions $(n=3,4)$ and derivatives ${ }^{8}$ (Figs 5 and 6) based on predictable functional group chemistry.

The Mo- $-\eta^{2}-S_{2}$ functional groups in the $\mathbf{L}_{x}(\mathrm{~S}) \mathrm{Mo}-\eta^{2}-\mathrm{S}_{2}$ complexes react with both electrophilic and nucleophilic reagents. Nucleophilic attack by triphenylphosphine, presumably on a highly polarized $\mathrm{S}_{2}^{2-}$ ligand, occurs readily and the ligand undergoes desulphurization with generation of $L_{x}(S) M o=S$ units. This general sulphur-abstraction reaction has been used effectively for the synthesis of various members of the $\left[\mathrm{Mo}_{2}^{\mathrm{V}}\right.$ $\left.(\mathbf{S})_{n}\left(\mathbf{S}_{2}\right)_{6-n}\right]^{2-}{ }^{2}$ and $\left[\mathrm{Mo}_{2}^{\mathrm{Y}}(\mathrm{O})(\mathbf{S})_{n}\left(\mathbf{S}_{2}\right)_{5-n}\right]^{2-7}$ series (Figs 3, 5 and 6) from "sulphur-rich" precursors. 

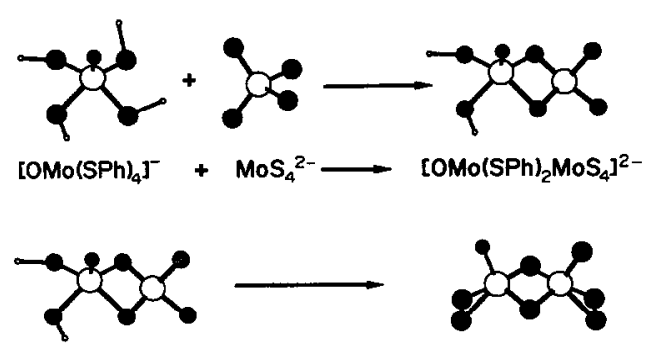

$\left[\mathrm{OMO}(\mathrm{SPh})_{2} \mathrm{MOS}_{4}\right]^{2-}+4 \mathrm{RSSSR} \rightarrow$ [III]

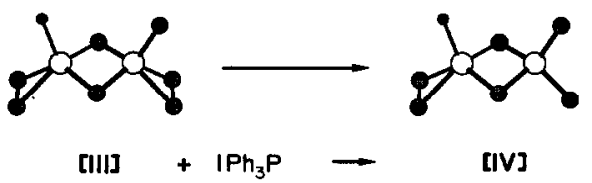

Fig. 5. Syntheses of members of the $\left[\mathrm{Mo}_{2}^{\mathrm{v}}(\mathrm{O})(\mathrm{S})_{n}\left(\mathrm{~S}_{2}\right)_{5-n}\right]^{2}$ series $(n=3,4)$ from $\left[(\mathrm{PhS})_{2} \mathrm{Mo}^{\mathrm{v}}(\mathrm{O})\left(\mathrm{Mo}^{\mathrm{vI}} \mathrm{S}_{4}\right)\right]^{-}$.

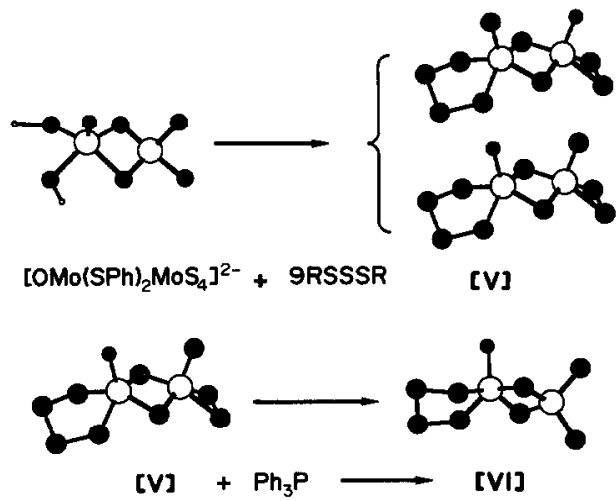

Fig. 6. Synthesis of electron redistribution isomers of the $\left[\mathrm{Mo}_{2}^{\mathrm{V}}(\mathrm{O})(\mathrm{S})_{n}\left(\mathrm{~S}_{2}\right)_{5-n}\right]^{2-}$ series $(n=1,2)$ from $\left[(\mathrm{PhS})_{2}\right.$ $\left.\mathrm{Mo}^{\mathrm{v}}(\mathrm{O})\left(\mathrm{Mo}^{\mathrm{v}} \mathrm{S}_{4}\right)\right]^{-}$.
The reaction of $\mathrm{Ph}_{3} \mathrm{P}$ with the $\mathrm{L}_{x}(\mathrm{O}) \mathrm{Mo}^{\mathrm{v}}-\eta^{2}$ $\mathrm{S}_{2}$ complexes probably proceeds with formation of $\mathrm{L}_{x}(\mathrm{O}) \mathrm{Mo}^{\mathrm{v}}=\mathrm{S}$ units that readily dimerize to the $\left[\mathrm{L}_{x}(\mathrm{O}) \mathbf{M o}^{\mathrm{v}}=\mathrm{S}\right]_{2}$ complexes (Fig. 2). The greater tendency of the $\mathrm{L}_{x}(\mathrm{O}) \mathrm{Mo}^{\mathrm{v}}=\mathrm{S}$ units to dimerize, by comparison to $\mathrm{L}_{x}(\mathrm{~S}) \mathrm{Mo}^{\mathrm{v}}=\mathrm{S}$ units, could be attributed in part to steric effects. The molybdenum(V) ions in the four-coordinate $\mathrm{L}_{x}(\mathrm{O}) \mathrm{Mo}^{\mathrm{v}}=\mathrm{S}$ units are not only coordinatively unsaturated but considerably less crowded than the molybdenum(V) ions in the $\mathrm{L}_{x}(\mathrm{~S}) \mathrm{Mo}^{\mathrm{v}}=\mathrm{S}$ units. The importance of this type of steric effect also is apparent in the synthesis of the $\left[\left(\mathrm{S}_{4}\right) \mathrm{Mo}^{\mathrm{IV}}(\mathrm{O})\left(\mathrm{Mo}^{\mathrm{vI}} \mathrm{S}_{4}\right)\right]^{2-}$ complex. ${ }^{7}$ This anion (but not the isomeric $\left[\left(\mathrm{S}_{4}\right) \mathrm{Mo}^{\mathrm{IV}}(\mathrm{S})\right.$ $\left.\left.\left(\mathrm{Mo}^{\mathrm{VI}} \mathrm{S}_{3} \mathrm{O}\right)\right]^{2-}\right)$ is obtained exclusively in the reaction of a 50:50 mixture of the $\left[\left(\mathrm{S}_{4}\right) \mathrm{Mo}^{\mathrm{v}}(\mathrm{O})(\mu-\mathrm{S})_{2} \mathrm{Mo}^{\mathrm{v}}\right.$ $\left.(\mathbf{S})\left(\mathrm{S}_{2}\right)\right]^{2-}$ and $\left[\left(\mathrm{S}_{4}\right) \mathrm{Mo}^{\mathrm{v}}(\mathrm{S})(\mu-\mathrm{S})_{2} \mathrm{Mo}^{\mathrm{v}}(\mathrm{O})\left(\mathrm{S}_{2}\right)\right]^{2-}$ isomers with $\mathrm{Ph}_{3} \mathrm{P}$ (Fig. 6). A similar preferential sulphur abstraction from a $\operatorname{Mo}(\mathbf{S})\left(\eta^{2}-\mathbf{S}_{2}\right)$ functional group is also apparent in the exclusive synthesis of the $\left[\left(\mathrm{S}_{2}\right) \mathrm{Mo}^{\mathrm{IV}}(\mathrm{O})\left(\mathrm{Mo}^{\mathrm{VI}} \mathrm{S}_{4}\right)\right]^{2-}$ anion $^{7}$ from $\left[\left(\mathrm{S}_{2}\right) \mathbf{M o}^{\mathrm{v}}(\mathrm{O})(\mu-\mathrm{S})_{2}(\mathrm{~S}) \mathbf{M o}^{\mathrm{v}}\left(\mathbf{S}_{2}\right)\right]^{2-}$ (Fig. 5).

In DMF solution, $\mathrm{I}_{2}$ oxidation of $\eta^{2}-\mathrm{S}_{2}^{2-}$ ligands gives polymeric thiomolybdates when neighbouring terminal $\mathrm{S}^{2-}$ ligands are also present on the same molybdenum atom. If instead of $\mathrm{S}^{2-}$ a neighbouring $\mathrm{O}^{2-}$ ligand is present on the molybdenum atom, the $\mathrm{S}_{2}^{2-}$ ligands are oxidatively removed (as $\mathrm{S}_{8}$ ) and are replaced by DMF ligands ${ }^{8}$ (Fig. 7). The neutral $\left[\left(\mathrm{S}_{2}\right) \mathbf{M o}^{\mathrm{v}}(\mathbf{O})\left(\mu-\mathrm{S}_{2} \mathrm{Mo}^{\mathrm{v}}(\mathrm{O})(\mathrm{DMF})_{3}\right]\right.$ complex, and the $\mathrm{I}^{-}$salt of the $\left[(\mathrm{DMF})_{3} \mathrm{Mo}^{\mathrm{v}}(\mathrm{O})(\mu\right.$ $\left.\mathrm{S}_{2} \mathrm{Mo}^{\mathrm{v}}(\mathrm{O})(\mathrm{DMF})_{3}\right]^{2+}$ cation have been obtained in excellent yields in crystalline form. ${ }^{8}$ These complexes have made it possible to synthesize a wide

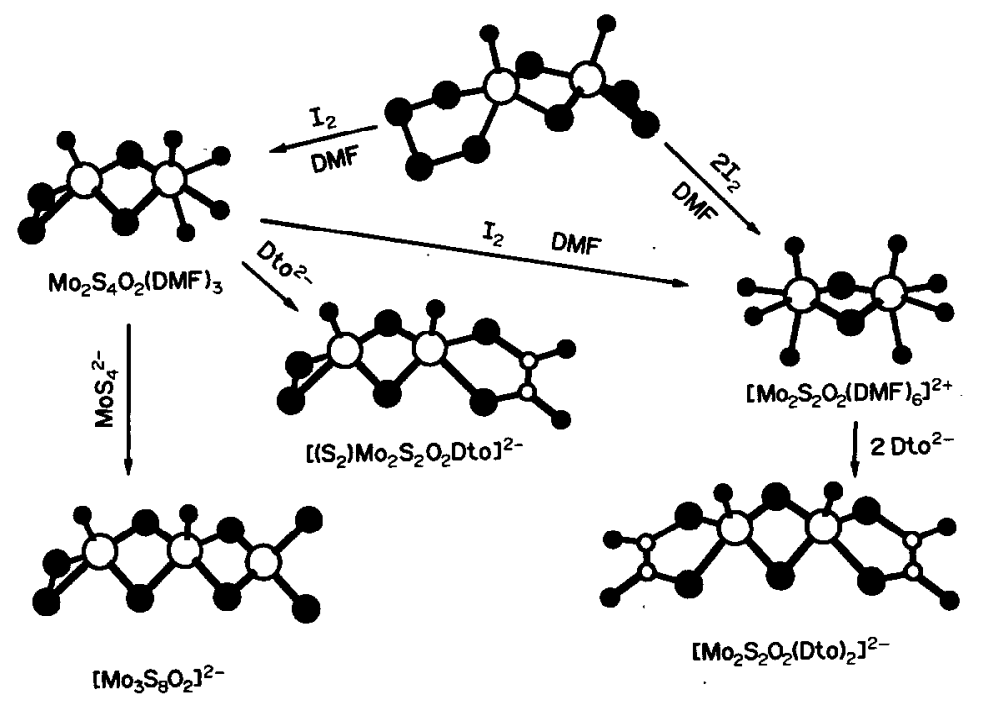

Fig. 7. Iodine oxidation of the $\mathrm{S}_{x}^{2-}$ ligands in the $\left[\left(\mathrm{S}_{4}\right) \mathbf{M o}^{\mathrm{v}}(\mathrm{O})(\mu-\mathrm{S})_{2} \mathbf{M o}^{\mathrm{v}}(\mathrm{O})\left(\mathrm{S}_{2}\right)\right]^{2-}$ complex. Synthesis and derivatives of the $\left[(D M F)_{3} \mathbf{M o}^{\mathrm{v}}(\mathrm{O})(\mu-\mathrm{S})_{2} \mathrm{Mo}^{\mathrm{v}}(\mathrm{O})\left(\mathrm{S}_{2}\right)\right]$ and $\left[(\mathrm{DMF})_{3} \mathrm{Mo}^{\mathrm{v}}(\mathrm{O})\left(\mu-\mathrm{S}_{2} \mathrm{Mo}^{\mathrm{v}}(\mathrm{O})\right.\right.$ $\left.(\mathrm{DMF})_{3}\right]^{2+}$ complexes. 


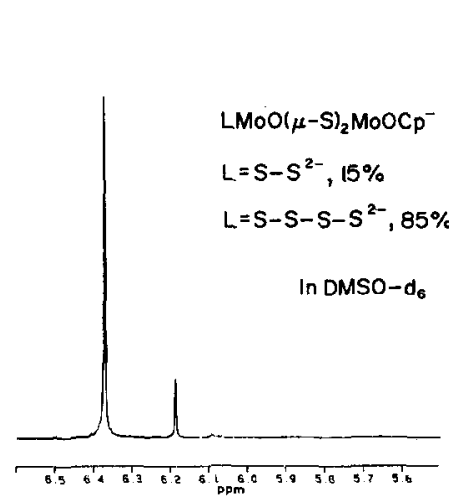

(A)

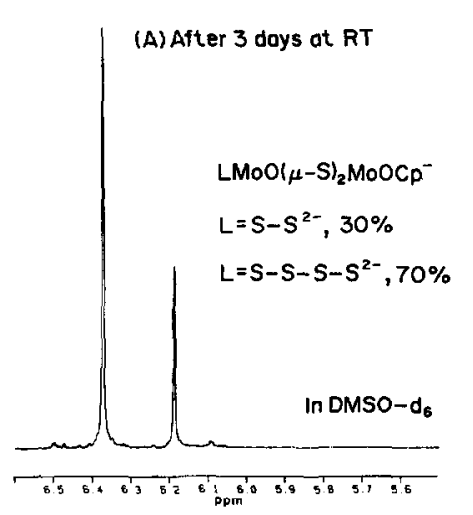

(B)

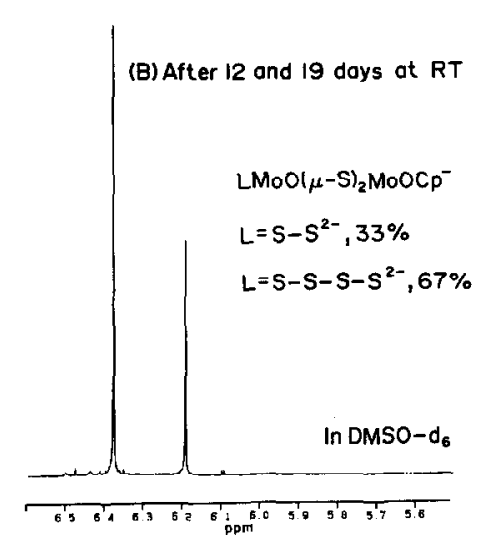

(C)

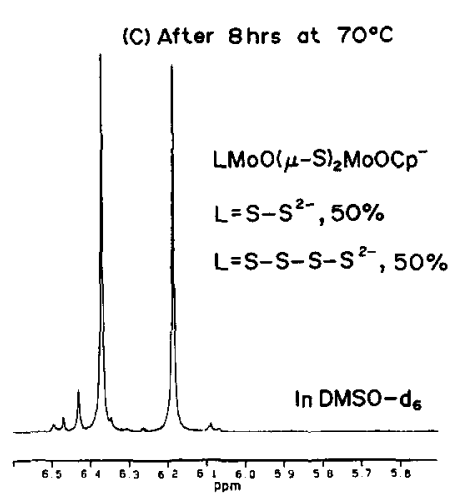

(D)

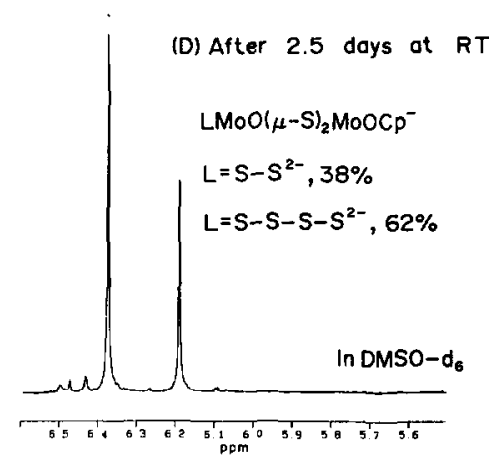

(E)

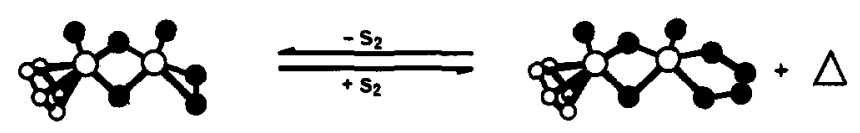

Fig. 8. 'H NMR study of the $\mathrm{Cp}^{-}$ligand in the $\left[(\mathrm{Cp}) \mathrm{Mo}^{\mathrm{v}}(\mathrm{O})(\mu-\mathrm{S})_{2} \mathrm{Mo}^{\mathrm{v}}(\mathrm{O})\left(\mathrm{S}_{2}\right)\right]^{-}$and $\left[(\mathrm{Cp}) \mathrm{Mo}^{\mathrm{v}}(\mathrm{O})\right.$ $\left.(\mu-\mathrm{S})_{2} \mathrm{Mo}^{\mathrm{v}}(\mathrm{O})\left(\mathrm{S}_{4}\right)\right]$ complexes at equilibrium.

variety of complexes containing the $\left[\mathrm{Mo}_{2}^{\mathrm{v}}(\mathrm{O})_{2}\right.$ $\left.(\mu-\mathrm{S})_{2}\right]^{2+}$ core by replacement of the labile DMF ligands (Fig. 7).

\section{The molybdenum-coordinated $\mathrm{S}_{4}^{2-}$ ligands}

Addition of elemental sulphur to the Mo$\eta^{2}-S_{2}$ functional group results in the formation of the Mo- $\eta^{2}-\mathrm{S}_{4}$ unit, in a reaction that could be visualized as an insertion of a polarized ${ }^{\delta+} \mathbf{S}-\mathbf{S}^{\delta-}$ species into the $\mathrm{Mo}-\mathrm{S}_{2}$ bond. This insertion is reversible and in solution the $\mathrm{Mo}-\eta^{2}-\mathrm{S}_{4}$ group exists in equilibrium with $\mathrm{Mo}-\eta^{2}-\mathrm{S}_{2}$ and elemental sulphur.

This equilibrium has been established unequivocally by an ${ }^{1} \mathrm{H}$ NMR study of mixtures of

\footnotetext{
* See footnote $\uparrow$ on p. 1705.
}

the $\left[(\mathrm{Cp}) \mathrm{Mo}^{\mathrm{v}}(\mathrm{O})(\mu-\mathrm{S})_{2} \mathrm{Mo}^{\mathrm{v}}(\mathrm{O}) \mathrm{S}_{4}\right]^{-}$and $\left[(\mathrm{Cp}) \mathbf{M o}^{\mathrm{v}}\right.$ (O) $\left.(\mu-\mathrm{S})_{2} \mathrm{Mo}^{\mathrm{v}}(\mathrm{O}) \mathrm{S}_{2}\right]^{-}$anions in $\mathrm{CH}_{3} \mathrm{CN}$ solution (Fig. 8). Such a mixture, that contains the $\left[(\mathrm{Cp}) \mathrm{Mo}^{\mathrm{v}}\right.$ $\left.(\mathrm{O})(\mu-\mathrm{S})_{2} \mathrm{Mo}^{\mathrm{V}}(\mathrm{O}) \mathrm{S}_{4}\right]^{-}$anion as the major component $(84 \%)$, is obtained ${ }^{21}$ in the reaction between $\left[(\mathrm{Cp}) \mathrm{Mo}^{\mathrm{V}}(\mathrm{O})(\mu-\mathrm{S})_{2} \mathrm{Mo}^{\mathrm{V}}(\mathrm{O})(\mathrm{DMF})_{3}\right]^{+}$and an excess of $\left(\mathrm{NH}_{4}\right)_{2} \mathrm{~S}_{x}$. The $\left[(\mathrm{Cp}) \mathrm{Mo}^{\mathrm{v}}(\mathrm{O})(\mu-\mathrm{S})_{2} \mathrm{Mo}^{\mathrm{v}}(\mathrm{O})\right.$ $\left.(\mathrm{DMF})_{3}\right]^{+}$cation is obtained by $\mathrm{I}_{2}$ oxidation of the $\left[(\mathrm{Cp}) \mathrm{Mo}^{\mathrm{v}}(\mathrm{O})(\mu-\mathrm{S})_{2} \mathrm{Mo}^{\mathrm{v}}(\mathrm{O}) \mathrm{S}_{2}\right]^{-}$complex in DMF solution. It is now apparent that the chemistry of the Mo- $\eta^{2}-S_{4}$ group is dominated by the presence of the Mo- $\eta^{2}-\mathrm{S}_{2}$ groups. The ready dissociation of $S_{2}$ from the coordinated $S_{4}^{2-}$ ligand is due to a weakening of the $\mathrm{S}-\mathrm{S}$ bonds proximal to the molybdenum atom. This weakening has been attributed previously to Mo-S $d \pi-p \pi$ bonding ${ }^{1,19, *}$ and is reflected in unusually long $\mathrm{S}-\mathrm{S}$ bond lengths in the coordinated ligand. 
Reactivity of the molybdenum-coordinated $\mathrm{S}_{x}^{2-}$ ligands toward unsaturated electrophilic molecules

The reaction chemistry of the molybdenum thioanions with electrophiles such as $\mathrm{CS}_{2}{ }^{1,14}$ and dicarboalcoxyacetylenes ${ }^{1,15}$ has been investigated in considerable detail. It appears that both the $\mathrm{Mo}-\eta^{2}-\mathrm{S}_{x}$ and $\mathrm{Mo}=\mathrm{S}$ groups are sufficiently nucleophilic to attack by dicarbomethoxyacetylene (DMA). This is clearly established for thiomolybdates that contain both $\mathrm{Mo}=\mathrm{S}$ and $\mathrm{Mo}\left(\eta^{2}-\right.$ $\left.\mathrm{S}_{x}\right)$ groups. The reactions of the $\left[\left(\mathrm{S}_{4}\right)_{2} \mathrm{Mo}^{\mathrm{IV}}=\mathrm{S}\right]^{2-}$ and $\left[\left(\mathbf{S}_{4}\right)(\mathbf{S}) \mathbf{M o}^{\mathrm{v}}(\mu-\mathbf{S}){ }_{2} \mathbf{M o}^{\mathrm{v}}(\mathbf{S})\left(\mathbf{S}_{2}\right]^{2-}\right.$ complexes with DMA (Fig. 9) proceed until all $S_{x}^{2-}$ sulphido ligands (with the exception of the $\mu$-S ${ }^{2-}$ ligands) are converted into the dithiolene (DMAD) ligands. The type of DMAD complex obained depends on the synthetic conditions. Thus, the $\left[\left(\mathrm{S}_{4}\right)_{2} \mathrm{Mo}^{\mathrm{IV}}=\mathrm{S}\right]^{2-}$ complex under anaerobic conditions reacts with DMA to give the $\left[\mathrm{Mo}^{\mathrm{IV}}(\mathrm{DMAD})_{3}\right]^{2-}$ complex. ${ }^{15}$ Under aerobic conditions the same reaction affords the dimeric [(DMAD) ${ }_{2} \mathrm{Mo}^{\mathrm{v}}(\mu-\mathrm{S})_{2} \mathrm{Mo}^{\mathrm{v}}$ $\left.(\mathrm{DMAD})_{2}\right]^{2-} .1$ The latter is also obtained from reactions of DMA with either the $\left[\left(\mathbf{S}_{4}\right)(\mathbf{S}) \mathbf{M o}^{\mathrm{v}}\right.$ $\left.(\mu-\mathbf{S})_{2} \mathbf{M o}^{\mathrm{v}}(\mathbf{S})\left(\mathbf{S}_{2}\right)\right]^{2-}$ or the $\left[\left(\mathbf{S}_{2}\right)(\mathbf{S}) \mathbf{M o}^{\mathrm{v}}(\mu-\mathbf{S}){ }_{2} \mathbf{M o}^{\mathrm{v}}\right.$ $\left.(\mathbf{S})\left(\mathbf{S}_{2}\right)\right]^{2-}$ complex anions. Possible reaction pathways are shown in Fig. 9. The formation of the DMAD ligands in these complexes can be ex-

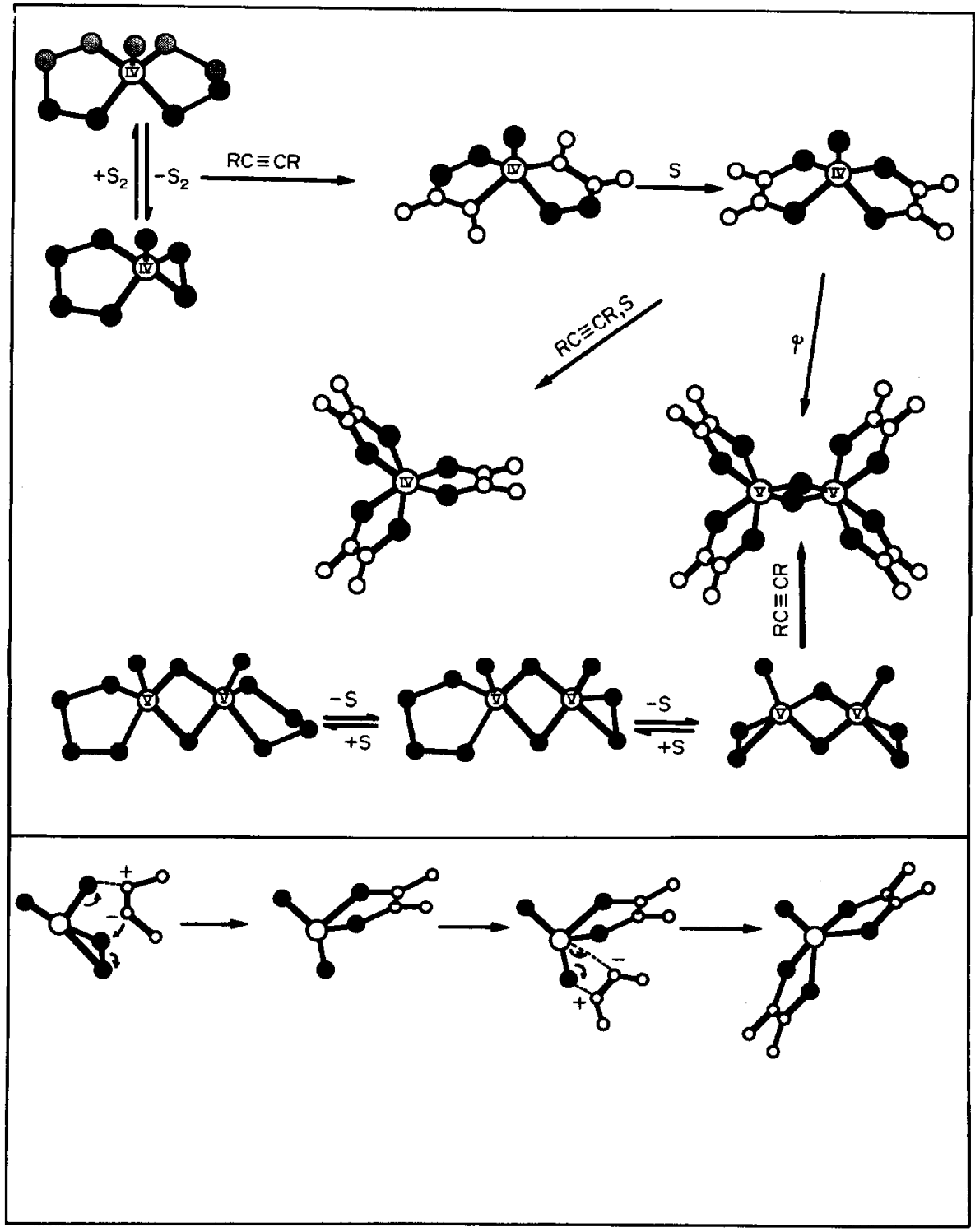

Fig. 9. Reactions of dicarbomethoxyacetylene, DMA, with the $\left[\left(\mathrm{S}_{4}\right)_{2} \mathbf{M o}^{\mathrm{IV}}=\mathbf{S}\right]^{2-}$ and $\left[\left(\mathrm{S}_{4}\right) \mathrm{Mo}^{\mathrm{V}}(\mathrm{S})\right.$ $\left.(\mu-\mathrm{S})_{2} \mathrm{Mo}^{\mathrm{V}}(\mathbf{S})\left(\mathrm{S}_{2}\right)\right]^{2-}$ complexes, under aerobic and anaerobic conditions. 
plained in terms of electrophilic attack by DMA on either the $\mathrm{Mo}=\mathrm{S}$ or the Mo- $\eta^{2}-\mathrm{S}_{2}$ functional groups. The initial step in these reactions is difficult to ascertain, but it could be electrophilic attack by DMA followed by insertion into either the $\mathrm{Mo}=\mathrm{S}$ or $\mathrm{Mo}-\eta^{2}-\mathrm{S}_{2}$ bonds. These insertions lead to the formation of reactive vinyl sulphide or vinyl disulphide ligands, that eventually transform to dithiolenes. This transformation could occur for the vinal sulphide by insertion of sulphur into the Mo- $-\mathrm{C}$ bond, and for the vinyl disulphide by a thermal or sulphur-catalysed isomerization reaction. Other possible schemes suggested previously ${ }^{15}$ for the addition of an alkyne into the Mo-S-S unit include: (a) direct formation of the DMAD dithiolene ligand, by electrophilic attack of DMA on the $\eta^{2}-S_{2}$ ligand, followed by insertion into the S-S bond and (b) a 4+2 Diels-Alder cycloaddition reaction.

The reactions of oxothiomolybdates with DMA (Fig. 10) have been quite useful from a mechanistic point of view. Replacement of the $\mathrm{Mo}=\mathrm{S}$ groups by the apparently unreactive $\mathrm{Mo}=\mathrm{O}$ groups, in otherwise isostructural complexes, simplifies the reactivity patterns and eliminates some of the ambiguities inherent in the reactions of totaly "sulphided" thiomolybdates.

The initial report ${ }^{22}$ on the synthesis of the vinyl disulphide complex, $\left[(\mathrm{L})(\mathrm{O}) \mathrm{Mo}^{\mathrm{v}}(\mu-\mathrm{S}){ }_{2} \mathrm{Mo}^{\mathrm{v}}(\mathrm{O})\right.$ $(\mathrm{L})]^{2-}\left(\mathrm{L}=[-(\mathrm{R}) \mathrm{C}=\mathrm{C}(\mathrm{R})-\mathrm{S}-\mathrm{S}-]^{2}\right)$, from the reaction of DMA with the $\left[\left(\mathbf{S}_{2}\right)(\mathrm{O}) \mathrm{Mo}^{\mathrm{v}}(\mu-\mathrm{S})_{2}\right.$ $\left.\mathrm{Mo}^{\mathrm{v}}(\mathrm{O})\left(\mathrm{S}_{2}\right)\right]^{2-}$ anion, revealed unequivocally that in the $(\mathrm{O}) \mathrm{Mo}\left(\mathrm{S}_{2}\right)$ structural subunits of the thiomolybdate anions, insertion into the Mo-S bond is prevalent. Subsequently, we have observed that the vinyl disulphide complex thermally isomerizes to the [(DMAD)(O) $\mathbf{M o}^{\mathrm{v}}(\mu-\mathrm{S}){ }_{2} \mathbf{M o}^{\mathrm{v}}$ (O)(DMAD) $]^{2-}$ dithiolene complex. The latter and also the $\left[(\mathrm{DMAD}){ }_{2} \mathrm{Mo}^{\mathrm{IV}}=\mathrm{O}\right]^{2-}$ complex are obtained directly from the reactions of the $\left[\left(\mathrm{S}_{4}\right)(\mathrm{O}) \mathrm{Mo}^{\mathrm{v}}(\mu-\mathrm{S})_{2} \mathrm{Mov}^{\mathrm{v}}(\mathrm{O})\left(\mathrm{S}_{2}\right)\right]^{2-}$ and $\left[\left(\mathrm{S}_{4}\right)_{2} \mathrm{Mo}^{\mathrm{IV}}=\right.$ $\mathrm{O}^{2-}$ anions, respectively, with $\mathrm{DMA}^{1}$ (Fig. 10). Isomerization of vinyl disulphide ligands to dithiolenes also has been reported to proceed via a firstorder reaction in the $(\mathrm{Cp})_{2} \mathrm{Ti}$ (vinyl disulphide) complex. ${ }^{23}$

The $\mathbf{S}_{4}^{2-}$ ligands play an indirect but important role in promoting the formation of dithiolenes, by supplying dissociated " $\mathrm{S}_{2}$ " that catalyses the vinyl disulphide to dithiolene conversion.

Convincing evidence for the catalytic effects of sulphur in this interconversion has been obtained from ${ }^{1} \mathrm{H}$ NMR studies of the DMA derivatives of the $\left[(\mathrm{Cp}) \mathrm{Mo}^{\mathrm{v}}(\mathrm{O})(\mu-\mathrm{S})_{2} \mathrm{Mo}^{\mathrm{v}}(\mathrm{O}) \mathrm{S}_{2}\right]^{-}$complex. ${ }^{24}$ This complex initially reacts with DMA to give a vinyl disulphide derivative by insertion of DMA into the $\mathrm{Mo}-\eta^{2}-\mathrm{S}_{2}$ group. Upon prolonged heating to $70^{\circ} \mathrm{C}$ the vinyldisulphide ligand in this complex is converted quantiatively to a dithiolene ligand. The same conversion takes place swiftly at the same temperature when catalytic amounts of $\mathbf{S}_{8}$ are added to $\mathrm{CH}_{3} \mathrm{CN}$ solutions of the vinyl disulphide complex. A plausible reaction pathway for the thermal, vinyl disulphide-dithiolene conversion initially

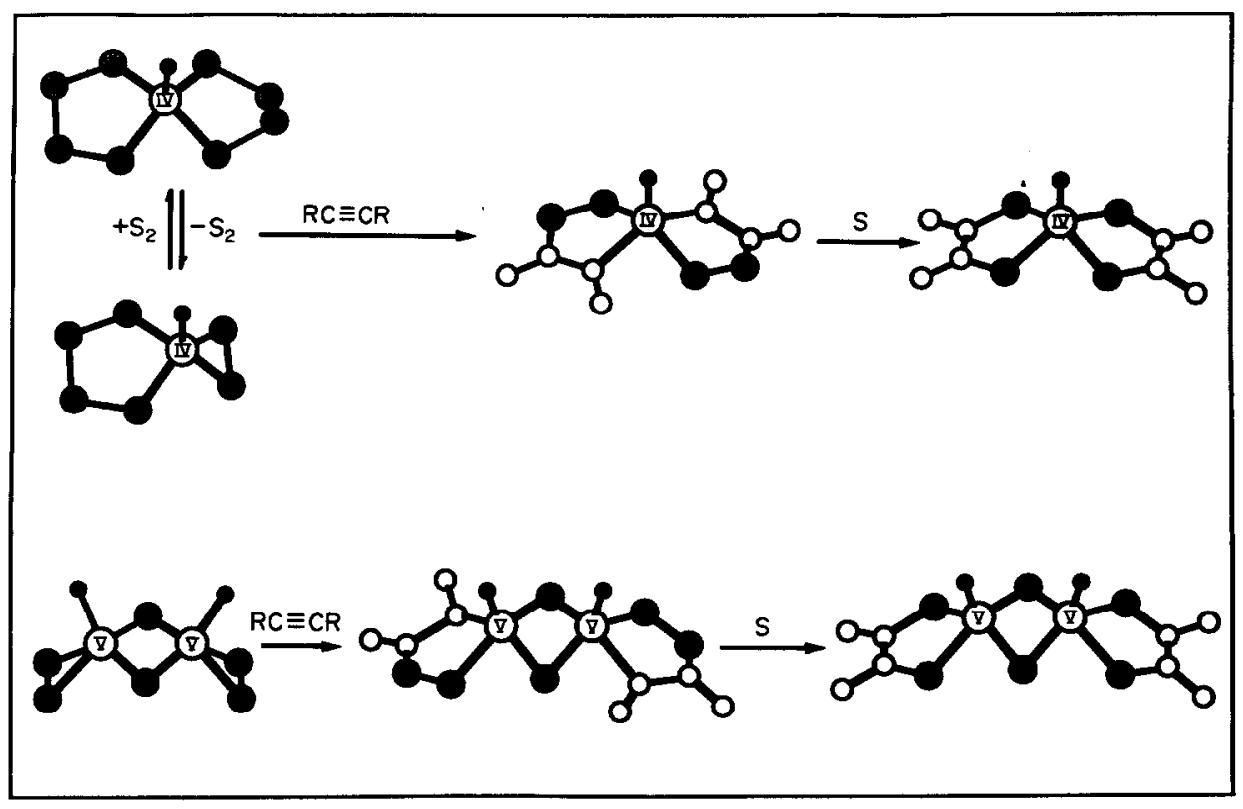

Fig. 10. Reactions of DMA with the $\left[\left(\mathrm{S}_{4}\right)_{2} \mathrm{Mo}^{\mathrm{Iv}}=\mathrm{O}^{2-}\right.$ and $\left[\left(\mathrm{S}_{4}\right) \mathrm{Mo}^{\mathrm{v}}(\mathrm{O})(\mu-\mathrm{S})_{2} \mathrm{Mo}^{\mathrm{v}}(\mathrm{O})\left(\mathrm{S}_{2}\right)\right]^{2-}$ complexes. 
may involve dissociation of a sulphur atom (the one adjacent to the olefinic bond) from the vinyl disulphide complex. The resulting vinyl sulphide complex is expected to be quite reactive and should readily undergo sulphur insertion reactions into the Mo- $\mathrm{C}$ bond to give a dithiolene complex. Preliminary results support this proposed sequence of reactions. Thus in the reaction of the $\left[(\mathrm{Cp}) \mathrm{Mo}^{\mathrm{v}}(\mathrm{O})\right.$ $\left.(\mu-\mathrm{S})_{2} \mathrm{Mo}^{\mathrm{v}}(\mathrm{O})((\mathrm{R}) \mathrm{C}=\mathrm{C}(\mathrm{R})-\mathrm{S}-\mathrm{S})\right]^{-}$vinyl disulphide complex, with one equivalent of $\mathrm{Ph}_{3} \mathrm{P}$, the two $\mathrm{CH}_{3}$ resonances of the vinyl disulphide ligand are replaced completely and cleanly by two new resonances that we attribute to the vinyl sulphide complex (Fig. 11). Addition of sulphur to this solution of the vinyl sulphide complex gives a $2: 1$ dithiolene-vinyl disulphide mixture. This experiment suggests that the assumed coordinated vinyl sulphide ligand can undergo sulphur insertion at either the Mo-S or the Mo- $\mathrm{C}$ bonds, and that insertion into the $\mathrm{Mo}-\mathrm{C}$ bond is a more facile process.

The sulphur-catalysed, vinyl disulphide-dithiolene conversion is proposed to proceed via formation of catalytic amounts of the "sulphur-rich" dithiolene complex by sulphur insertion into the Mo- $\mathrm{C}$ bond of the vinyl disulphide complex (Fig.
12). Precedence for the insertion of sulphur into a $\mathrm{M}-\mathrm{C}$ bond exists in the reaction of the [ $\eta^{5}$ Cp)W(NO)( $\left(\mathrm{CH}_{2} \mathrm{SiMe}_{3}\right)_{2}$ ] complex with $\mathrm{S}_{8}$ to give $\left[\left(\eta \eta^{5}-\mathrm{Cp}\right) \mathrm{W}(\mathrm{NO})\left(\mathrm{SCH}_{2} \mathrm{SiMe}_{3}\right)_{2}\right] .{ }^{25}$ Once formed, the "sulphur-rich" dithiolene complex is expected to undergo nucleophilic attack by the molybdenumbound carbon atom of the vinyl disulphide ligand. This attack should occur at the electrophilic sulphur atom adjacent to the ethylenic double bond in the "sulphur-rich" dithiolene and will result in sulphur abstraction, formation of dithiolene and regeneration of a sulphur-rich dithiolene that will repeat the cycle. In the scheme shown in Fig. 12 a large excess of sulphur is expected to quench the formation of dithiolene by conversion of most of the vinyl disulphide complex to the "sulphur-rich" dithiolene complex. The latter should be stable in the absence of nucleophilic "sulphur-acceptor" molecules. Indeed, we have observed (by ${ }^{1} \mathrm{H}$ NMR) a retardation in the rate of formation of dithiolene as larger than catalytic amounts of sulphur are added to the reaction medium.

The importance of alkyne insertion into Mo-S bonds and the formation of vinyl disulphide complexes preceding the formation of dithiolenes, still
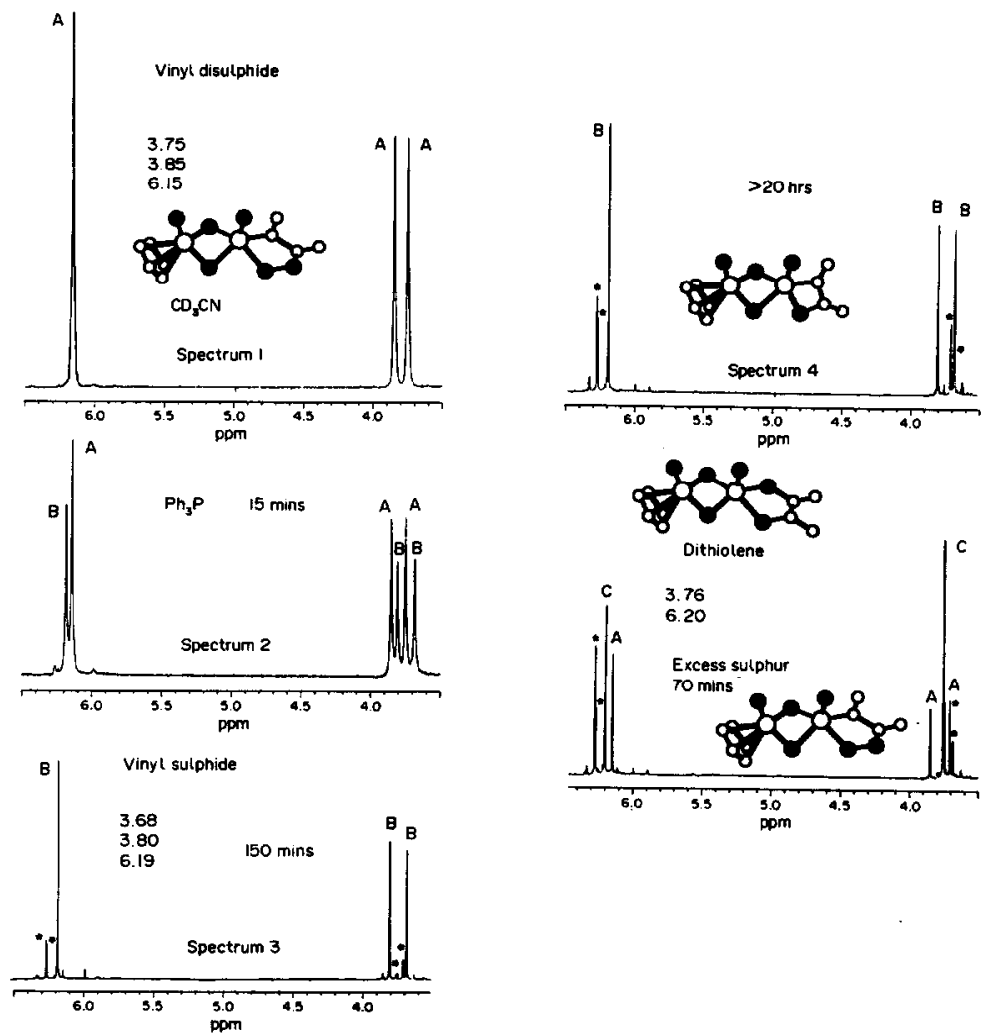

Fig. 11. Addition of triphenyl phosphine to a $\mathrm{CH}_{3} \mathrm{CN}$ solution of the $\left[(\mathrm{Cp}) \mathrm{Mo}^{\mathrm{v}}(\mathrm{O})(\mu-\mathrm{S})_{2}\right.$ $\left.\mathrm{Mo}^{\mathrm{v}}(\mathrm{O})((\mathrm{R}) \mathrm{C}=\mathrm{C}(\mathrm{R})-\mathrm{S}-\mathrm{S})\right]^{-}$vinyl disulphide complex $(\mathbf{A})$ and the proposed generation of a vinyl sulphide analogue (B). Addition of elemental sulphur to this solution with the subsequent formation of the vinyl disulphide (A) and dithiolene (C) complexes. 


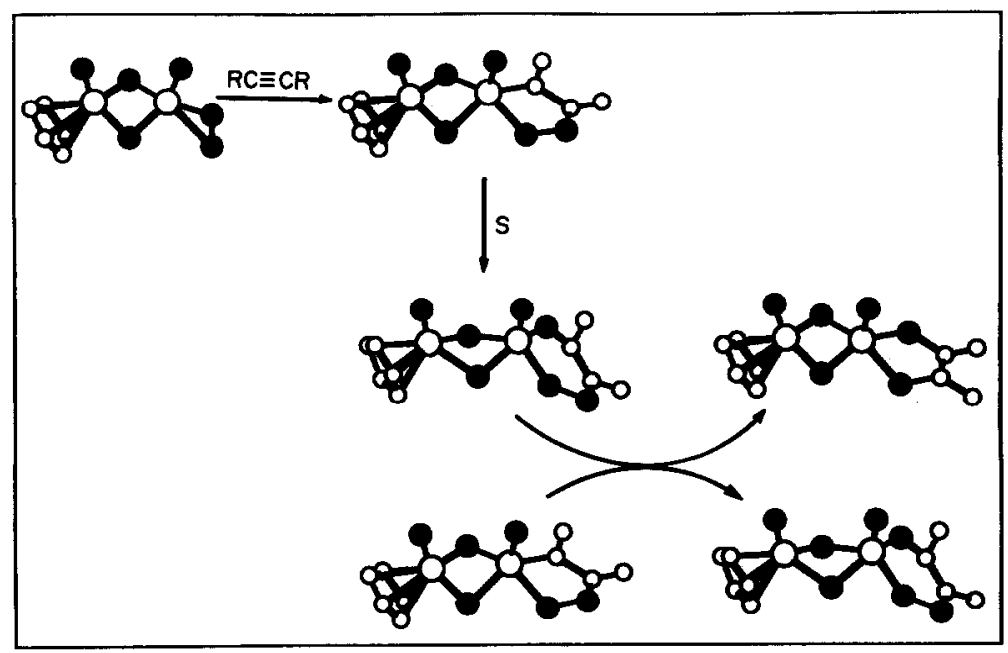

Fig. 12. A proposed reaction pathway, suggested by ${ }^{1} \mathrm{H}$ NMR spectroscopy, for the sulphur-catalysed transformation of the vinyl disulphide ligand in the $\left[(\mathrm{Cp}) \mathrm{Mo}^{\mathrm{v}}(\mathrm{O})(\mu-\mathrm{S})_{2} \mathrm{Mo}^{\mathrm{v}}(\mathrm{O})((\mathrm{R}) \mathrm{C}=\right.$ $\mathrm{C}(\mathbf{R})-\mathrm{S}-\mathrm{S})]^{-}$complex to a dithiolene ligand.

remain to be established for certain systems. This is particularly true for the synthesis of diothiolene complexes by the reaction of completely sulphided thiomolybdates with DMA (Fig. 9). To date we have been unable to detect evidence for the formation of a vinyl disulphide ligand in the reactions of DMA with any of the $\left[\mathrm{Mo}_{2}^{\mathrm{V}}(\mathrm{S})_{n}\left(\mathrm{~S}_{2}\right)_{6-n}\right]^{2-}$ complexes. It is entirely conceivable that the nucleophilic Mo-S sulphur atoms in the latter, first react with electrophiles that insert into the $\mathrm{Mo}=\mathrm{S}$ bond to give short lived vinyl sulphide species. Subsequent intramolecular sulphur transfer from the proximal $\eta^{2}-S_{x}^{2-}$ ligand rapidly results in the formation of dithiolenes.

The importance of the $\mathrm{Mo}=\mathrm{S}$ group is evident in the relative reactivities of the $\left[\left(\mathrm{S}_{4}\right)_{2} \mathrm{Mo}^{\mathrm{IV}}=\mathrm{O}\right]^{2-}$ and $\left[\left(\mathrm{S}_{4}\right)_{2} \mathrm{Mo}^{\mathrm{IV}}=\mathrm{S}\right]^{2-}$ complexes toward $\mathrm{CS}_{2}$. The latter readily reacts with $\mathrm{CS}_{2}$ to give both cis- and trans $-\left[\left(\mathrm{CS}_{4}\right)_{2} \mathrm{Mo}^{\mathrm{IV}}=\mathrm{S}\right]^{2-}$ complexes. $^{26}$ By comparison, the $\left[\left(\mathrm{S}_{4}\right)_{2} \mathrm{Mo}^{\mathrm{IV}}=\mathrm{O}\right]^{2-}$ complex is totally unreactive toward $\mathrm{CS}_{2}$. An exception to the facile oxidative dimerization of the $\left[(\mathrm{L})_{2} \mathrm{MoS}\right]^{2-}$ complexes is found with the $\left[\left(\mathrm{Cs}_{4}\right)_{2} \mathrm{Mo}^{\mathrm{IV}}=\mathrm{S}\right]^{2-}$ complex. This anion is quite stable and does not air-oxidize to the $\left[\left(\mathrm{CS}_{4}\right)_{2} \mathrm{Mo}^{\mathrm{v}}=\mathrm{S}_{2}^{2-}\right.$ product, at least under mild reaction conditions.

A remarkable characteristic of the $\mathrm{Mo}-\eta^{2}-\mathrm{CS}_{4}$ groups is their ability to reversibly release $\mathrm{CS}_{2}$ (Fig. 13) and revert to Mo- $-\eta^{2}-S_{2}$. On the basis of this observation, we have suggested previously ${ }^{1}$ that

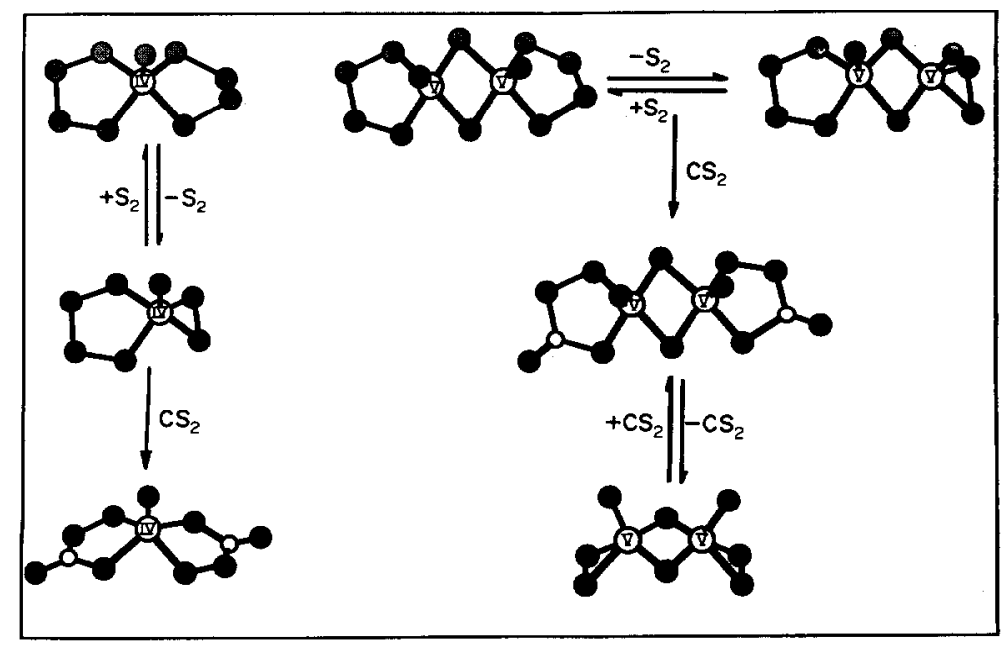

Fig. 13. Reversible addition of $\mathrm{CS}_{2}$ to the thiomolybdate complexes. 
Table 1. Comparison of the thiophene HDS activity ${ }^{a}$ over alumina-supported catalysts obtained from thiomolybdate precursors

\begin{tabular}{lccc}
\hline \multicolumn{1}{c}{ Catalyst precursor } & $\begin{array}{c}\text { Per cent } \\
\text { molybdenum } \\
\text { loading }\end{array}$ & TOF $^{b} \mathrm{C}_{4}\left(\mathrm{~s}^{-1}\right)$ & $\begin{array}{c}\text { Per cent } \\
\text { conversion, } \\
\mathrm{C}_{4}\end{array}$ \\
\hline$\left(\mathrm{Ni}(\mathrm{DMF})_{6}\right)\left[\mathrm{Mo}_{2} \mathrm{O}_{2} \mathrm{~S}_{8} \mathrm{Cl}_{2}\right.$ & 1.7 & $0.0021-0.0019$ & $54.3-47.5$ \\
$\left(\mathrm{Et}{ }_{4} \mathrm{~N}\right)\left[\mathrm{Mo}_{2} \mathrm{O}_{2} \mathrm{~S}_{8} \mathrm{Cl}\right]$ & 2 & $0.00028-0.00024$ & $4.2-3.5$ \\
$\left(\mathrm{Et}_{4} \mathrm{~N}\right)_{2}\left[\mathrm{Mo}_{4} \mathrm{O}_{4} \mathrm{~S}_{18}\right]$ & 2 & $0.00013-0.00014$ & $1.9-2.1$ \\
$\left(\mathrm{Ph}_{4} \mathrm{P}\right)_{2}\left[\mathrm{Mo}_{2} \mathrm{~S}_{6}\right]$ & 3.2 & $0.00015-0.00009$ & $8.3-5.2$ \\
Commercial Co-Mo-S & $d$ & $0.0011-0.0009$ & $29.6-25.3$ \\
"Catalco" & & & \\
\hline
\end{tabular}

\footnotetext{
${ }^{a}$ Vapour pressure of thiophene $=20$ torr, stream of hydrogen $=20 \mathrm{~cm}^{3} \mathrm{~min}^{-1}$.

${ }^{b}$ The figure of merit "TOF" is defined as the number of moles of desulphurized thiophene, per second, per mole of molybdenum. The first entry gives the TOF number within $30 \mathrm{~min}$ of thiophene conversion. The second value gives the TOF number after ca $3 \mathrm{~h}$ of thiophene conversion.

${ }^{c}$ The major products of thiophene conversion are $\mathrm{C}_{4}$ hydrocarbons. The ratio of trans/ cis-butene typically is $\sim 1.8 ; \mathrm{C}_{3}$ and $\mathrm{C}_{2}$ hydrocarbons are minor components.

${ }^{d}$ The commercial catalyst used as reference has a higher per cent metal loading: $12-$ $16 \% \mathrm{MoO}_{3}+2-5 \% \mathrm{CoO}$.
}

under certain conditions the Mo- $-\eta^{2}-S_{2}$ functional group may be directly involved in the activation of $\mathbf{C}-\mathbf{S}$ bonds in saturated or unsaturated sulphurcontaining organic molecules, in the catalysis of the hydrodesulphurization, HDS, reaction.

\section{Supported thiomolybdate complexes as catalysts for the hydrodesulphurization reaction}

The removal of sulphur from organosulphur compounds, present in crude petroleum, is carried out catalytically by the HDS reaction ${ }^{27}$ [eq. (1)]:

$$
\mathrm{RSH}+\mathrm{H}_{2} \longrightarrow \mathrm{H}_{2} \mathrm{~S}+\mathrm{RH} \text {. }
$$

The catalyst used industrially consists of "sulphided" molybdates supported on $\gamma-\mathrm{Al}_{2} \mathrm{O}_{3}$, although many second- and third-row transition metal sulphides are active catalysts for the HDS reaction, with $\mathrm{Ru}, \mathrm{Os}, \mathrm{Rh}$ and $\mathrm{Ir}$ sulphides showing the highest activity. ${ }^{28}$ Among the first-row transition metal ions, $\mathrm{Ni}^{2+}$ and $\mathrm{Co}^{2+}$ ions serve as promoters in the $\mathrm{MoS}_{2}$ HDS catalysis. ${ }^{27}$

Certain heteromtallic complexes have been used as precursors for the preparation of HDS catalysts.

* A detailed study of the catalytic properties of the thiomolybdate complexes is currently underway, in collaboration with Professor J. Schwank and Mr J. Lindner in the Department of Chemical Engineering, The University of Michigan. The results of this study will be published in detail elsewhere.
Among them are included: $\left[\left(\mathrm{WS}_{4}\right)_{2} \mathrm{Ni}\right]^{2-29}$ and $(\mathrm{MeCp})_{2} \mathrm{Mo}_{2} \mathrm{Co}_{2}\left(\mu_{3}-\mathrm{S}\right)_{2}\left(\mu_{4}-\mathrm{S}\right)(\mathrm{CO})_{4} \cdot{ }^{30}$ In a preliminary study the thiomolybdate salts $\left(\mathrm{Et}_{4} \mathrm{~N}\right)_{2}$ $\left[\left(\mathrm{S}_{4}\right)_{2} \mathrm{Mo}^{\mathrm{IV}}=\mathrm{O}\right]$ and $\left(\mathrm{Et}_{4} \mathrm{~N}\right)_{2}\left[\left(\mathrm{~S}_{4}\right)_{2} \mathrm{Mo}^{\mathrm{IV}}=\mathrm{S}\right]$ were used as precursors for alumina supported HDS catalysts in the absence of promoter ions. ${ }^{26} \mathrm{At}$ $205^{\circ} \mathrm{C}$, the catalyst obtained from $\left(\mathrm{Et}_{4} \mathrm{~N}\right)_{2}\left[\left(\mathrm{~S}_{4}\right)_{2}\right.$ $\left.\mathrm{Mo}^{\mathrm{IV}}=\mathrm{O}\right](3.1 \%$ loading) approached the activity shown by commercial Co-Mo catalysts, at the same temperature, and showed superior thiophene HDS activity then a similar "catalyst" obtained from $\left(\mathrm{Et}_{4} \mathrm{~N}\right)_{2}\left[\left(\mathrm{~S}_{4}\right)_{2} \mathrm{Mo}^{\mathrm{IV}}=\mathrm{S}\right]$. These results suggested that the $\mathrm{Mo}=\mathrm{O}$ groups may be important in HDS catalysis and prompted us to examine other thiomolybdate complex anions. The thiopheneHDS catalytic activities of the $\left(\mathrm{Et}_{4} \mathrm{~N}\right)\left[\mathrm{Mo}_{2} \mathrm{O}_{2} \mathrm{~S}_{8}\right.$ $\mathrm{Cl}],{ }^{31}\left[\mathrm{Ni}(\mathrm{DMF})_{6}\right]\left[\mathrm{Mo}_{2} \mathrm{O}_{2} \mathrm{~S}_{8} \mathrm{Cl}\right]_{2},{ }^{32}\left(\mathrm{Et}_{4} \mathrm{~N}\right)_{2}\left[\mathrm{Mo}_{4} \mathrm{O}_{4}\right.$ $\left.\mathrm{S}_{18}\right]^{17}$ and $\left(\mathrm{Ph}_{4} \mathrm{P}\right)_{2}\left[\mathrm{Mo}_{2} \mathrm{~S}_{6}\right]^{2}$ have been examined* (Table 1).

The $\left(\mathrm{Et}_{4} \mathrm{~N}\right)^{+}$cation in $\left(\mathrm{Et}_{4} \mathrm{~N}\right)\left[\mathrm{Mo}_{2} \mathrm{O}_{2} \mathrm{~S}_{8} \mathrm{Cl}\right]^{31}$ (Fig. 4) can be exchanged conveniently in the reaction of this compound with $\mathrm{NiCl}_{2} \cdot 6 \mathrm{H}_{2} \mathrm{O}$ in DMF solution. The black-red $\left[\mathrm{Ni}(\mathrm{DMF})_{6}\right]\left[\mathrm{Mo}_{2} \mathrm{O}_{2} \mathrm{~S}_{8} \mathrm{Cl}\right]_{2}$ salt has been isolated in $\sim 50 \%$ yield. ${ }^{33}$ The corresponding iodo complex, $\left[\mathrm{Ni}(\mathrm{DMF})_{6}\right]\left[\mathrm{Mo}_{2} \mathrm{O}_{2}\right.$ $\mathrm{S}_{8} \mathrm{I}_{2}$, has also been obtained by a similar reaction using $\mathrm{NiI}_{2} \cdot 6 \mathrm{H}_{2} \mathrm{O}^{32}$ The crystal and molecular structure of the latter was determined by X-ray crystallography ${ }^{32}$ and the structure of the anion is virtually identical to that of the $\left[\mathrm{Mo}_{2} \mathrm{O}_{2} \mathrm{~S}_{8} \mathrm{Cl}\right]^{-}$ anion $^{31}$ (Fig. 4). An examination of the preliminary results* reported in Table 1 shows that the 
$\mathrm{Ni} / \mathrm{Mo}$ catalyst obtained from $\left[\mathrm{Ni}(\mathrm{DMF})_{6}\right]\left[\mathrm{Mo}_{2}\right.$ $\left.\mathrm{O}_{2} \mathrm{~S}_{8} \mathrm{Cl}\right]_{2}$ is nearly 10 times more effective than a commercial $\mathrm{Co} / \mathrm{Mo}$ catalyst, on the basis of relative figure of merit values.* At present we are conducting detailed systematic studies of the HDS catalytic properties of the thiomolybdate anions and of the $\mathrm{Ni}^{2+}, \mathrm{Co}^{2+}$ and $\mathrm{Fe}^{2+}$ "salts" of these complexes.

Acknowledgements-The support of this work by a grant (CH-79-0389) from the National Science Foundation is greatefully acknowledged.

\section{REFERENCES}

1. D. Coucouvanis, A. I. Hadjikyriacou, M. Draganjac, M. G. Kanatzidis and O. Ileperuma, Polyhedron 1986, 5, 349.

2. A. I. Hadjikyriacou and D. Coucouvanis, Inorg. Chem. 1987, 26, 2400.

3. A. Muller, Polyhedron 1986, 5, 323.

4. M. A. Harmer, T. R. Halbert, W.-H. Pan, C. L. Coyle, S. A. Cohen and E. I. Stiefel, Polyhedron 1986, 5,341 .

5. E. Clementi and C. Roetti, At. Data Nucl. Data Tables 1974, 14, 3.

6. M. Draganjac, E. Simhon, L. T. Chan, M. Kanatzidis, N. C. Baenziger and D. Coucouvanis, Inorg. Chem. 1982, 21, 3321.

7. D. Coucouvanis and Sang-Man Koo, Inorg. Chem. $1989,28,2$.

8. D. Coucouvanis, A. Toupadakis and A. Hadjikyriacou, Inorg. Chem. 1988, $27,3272$.

9. T. R. Halbert, W. H. Pan and E. I. Stiefel, J. Am. Chem. Soc. 1983, 105, 5476.

10. A. Muller, R. G. Bhattacharyya and B. Pfefferkorn, Chem. Ber. 1979, 112, 778.

11. M. Martinez, B.-L. Ooi and A. G. Sykes, J. Am. Chem. Soc. 1987, 109, 4615.

12. T. Shibahara, H. Kuroya, K. Matsumoto and S. Ooi, J. Am. Chem. Soc. 1984, 106, 789.

13. T. Shibahara, T. Yamamoto, H. Kanadani and H. Kuroya, J. Am. Chem. Soc. 1987, 109, 3495.

14. D. Coucouvanis and M. Draganjac, J. Am. Chem. Soc. 1982, 104, 6820.

15. M. Draganjac and D. Coucouvanis, J. Am. Chem. Soc. 1983, 105, 139.

16. (a) D. Coucouvanis, E. D. Simhon and N. C. Baenziger, J. Am. Chem. Soc. 1980, 102, 6644; (b) J. W. McDonald, G. D. Friesen and W. E. Newton, Inorg. Chim. Acta 1980, 46, L79; (c) A. Muller, W.

* This figure of merit is defined as the number of moles of desulphurized thiophene, per second, per mole of molybdenum.
Hellmann, C. Romer, M. Romer, H. Bogge, R. Jostes and U. Schimanski, Inorg. Chim. Acta 1984, 83, L75; (d) W.-H. Pan, S. T. McKenna, R. R. Chianelli, T. R. Halbert, L. L. Hutchings and E. I. Stiefel, Inorg. Chim. Acta 1985, 97, L17 ; (e) A. Muller, F. Diemann, R. Jostes and H. Bogge, Angew. Chem. Int. Edn. Engl. 1981, 20, 934; (f) K. P. Callahan and P. A. Piliero, Inorg. Chem. 1980, 19, 2609; (g) D. Coucouvanis, P. Stremple, E. D. Simhon, D. Swenson, N. C. Baenziger, M. Draganjac, L. T. Chan, A. Simopoulos, V. Papaefthymiou, A. Kostikas and V. Petrouleas, Inorg. Chem. 1983, 22, 293 ; (h) D. Coucouvanis, N. C. Baenziger, E. D. Simhon, P. Stremple, D. Swenson, A. Kostikas, A. Simopoulos, V. Petrouleas and V. Papaefthymiou, J. Am. Chem. Soc. 1980, 102, 1730; (i) D. Coucouvanis, E. D. Simhon, P. Stremple, M. Ryan, D. Swenson, N. C. Baenziger, A. Simopoulos, V. Papaefthymiou, A. Kostikas and V. Petrouleas, Inorg. Chem. 1984, 23, 741-9; (j) D. Coucouvanis, Accts Chem. Res. 1981, 14, 201.

17. A. I. Hadjikyriacou and D. Coucouvanis, Inorg. Chem., in press.

18. D. Coucouvanis and A. I. Hadjikyriacou, Inorg. Chem. 1987, 26, 1.

19. D. Coucouvanis, P. R. Patil, M. G. Kanatzidis, B. Detering and N. C. Baenziger, Inorg. Chem. 1985, $24,24$.

20. (a) I. W. Boyd, I. G. Dance, K. S. Murray and A. G. Wedd, Aust. J. Chem. 1978, 31, 279; (b) J. R. Bradbury, M. F. Mackay and A. G. Wedd, Aust. J. Chem. 1978, 31, 2433.

21. A. Toupadakis and D. Coucouvanis, manuscript in preparation.

22. T. R. Halbert, W.-H. Pan and E. I. Stiefel, J. Am. Chem. Soc. 1983, 105, 5476.

23. M. Draganjac and T. B. Rauchfuss, Angew. Chem. Int. Edn Engl. 1985, 24, 742.

24. A. Toupadakis and D. Coucouvanis, to be published.

25. P. Legzdins and L. Sanches, J. Am. Chem. Soc. 1985, $107,5525$.

26. M. Draganjac, $\mathrm{PhD}$ thesis. University of Iowa (1983).

27. (a) F. E. Massoth, Adv. Catal. 1978, 27, 265; (b) J. Topsoe and B. S. Clausen, Catal. Rev.-Sci. Engng 1984, 26, 395; (c) O. Weisser and S. Landa, Sulfide Catalysts: Their Properties and Applications. Pergamon Press, London (1973).

28. T. Pecoraro and R. Chianelli, J. Catal. 1981, 67, 430.

29. W. Eltzner, M. Breyse, M. Lacroix, C. Leclerq, M. Vrinat, A. Muller and E. Diemann, Polyhedron 1988, 7, 2405.

30. M. D. Curtis and P. D. Williams, Inorg. Chem. 1983, 19, 2661.

31. A. I. Hadjikyriacou and D. Coucouvanis, Inorg. Chem., in press.

32. A. I. Hadjikyriacou, PhD thesis. University of Michigan (1988). 